\title{
Cancer risk in patients with IgA nephropathy: a Swedish population-based cohort study
}

Johanna Rehnberg, ${ }^{1,2}$, Jonas F. Ludvigsson ${ }^{3,4,5,6,}$ Juan-Jesus Carrero ${ }^{3}$, Louise Emilsson, ${ }^{2,3,7,8}$

${ }^{1}$ Department of Nephrology and Centre for Clinical Research, County Council of Värmland, Central Hospital Karlstad, Sweden

${ }^{2}$ School of Medical Science, University of Örebro, Örebro, Sweden

${ }^{3}$ Department of Medical Epidemiology and Biostatistics, Karolinska Institutet, Stockholm, Sweden

${ }^{4}$ Department of Pediatrics, Örebro University Hospital, Örebro, Sweden

${ }^{5}$ Division of Digestive and Liver Disease, Department of Medicine, Columbia University Medical Center, New York, New York, USA

${ }^{6}$ Division of Epidemiology and Public Health, School of Medicine, University of Nottingham, UK

${ }^{7}$ Nysäter Health Care Center and Centre for Clinical Research, County Council of Värmland, Sweden

${ }^{8}$ Department of General Practice, Institute of Health and Society, University of Osło, Oslo, Norway

Correspondence to: Louise Emilsson; E-mail: louise.emilsson@medisin.uio.no

\section{List of abbreviations:}

AER, absolute excess risk; CI, confidence interval; CKD, Chronic kidney disease; eGFR, estimated glomerular filtration rate; ESRD, end stage renal disease; HR, hazard ratio; ICD, International Classification of Diseases; IgAN, IgA nephropathy; NMSC, non-melanoma skin cancer; OR, odds ratio; SNOMED, Systematized Nomenclature of Medicine 


\section{ABSTRACT}

Background. IgA nephropathy (IgAN) is the most common primary glomerulonephritis affecting all ages and both sexes, but there is a lack of studies on its association with cancer and whether it is a paramalignant condition.

Methods. In a Swedish population-based cohort study we compared the risk of cancer among 3,882 biopsy-verified IgAN patients diagnosed during 1974-2011 with 19,341 reference individuals and followed them until 2015. Cox regression was used to estimate hazard ratios (HRs) for cancer in IgAN patients versus controls, and conditional logistic regression assessed the risk of cancer before the $\operatorname{IgAN}$ was confirmed.

Results. During a median follow-up of 12.6 years, 488 (12.6\%) patients with IgAN and 1,783 (9.2\%) matched reference individuals were diagnosed with cancer (HR 1.70; 95\% confidence interval, 95\% CI, 1.52-1.89). The increased risk was only seen in IgAN patients developing end stage renal disease (ESRD), with an HR of 4.01 (95\%CI 3.33-4.82) for any cancer and HR of 2.22 (95\%CI 1.79-2.75) when excluding non-melanoma skin cancer (NMSC). NonESRD IgAN patients did not have an increased overall cancer risk (HR 1.13; 95\%CI 0.991.30). There was no increased risk of cancer preceding $\operatorname{IgAN}$ diagnosis (odds ratio 1.10; 95\% CI 0.92-1.32).

Conclusion. We found no support for IgAN being a paramalignant condition. There was an increased risk of cancer in IgAN patients, but only for those with ESRD. Our results indicate approximately 6 extra cancer case per $100 \operatorname{IgAN}$ patients with ESRD per 10 years, or $>17$ extra cases if including NMSC as well.

Keywords: cancer risk, epidemiology, IgA nephropathy 


\section{KEY LEARNING POINTS}

\section{What is already known about this subject?}

- $\operatorname{Ig} \mathrm{A}$ nephropathy $(\operatorname{Ig} \mathrm{AN})$ is the most common primary glomerulonephritis worldwide.

-The association between glomerular disease and cancer has long been discussed, and IgAN has been implied to be a potential paramalignant condition.

\section{What this study adds?}

-This study is to our knowledge the largest epidemiological study investigating the association between cancer risk in IgAN specifically.

-We did not find any support for increased risk of cancer prior to an IgAN diagnosis, or of IgAN being a paramalignant condition.

-We found an increased risk of cancer in patients with IgAN but confined to those with end stage renal disease and especially in patients who had undergone a kidney transplant.

\section{What impact this may have on practice or policy?}

-An IgAN diagnosis does not seem to imply a higher risk of cancer, hence cancer screening does not seem to be needed in the average patient with $\operatorname{IgAN}$.

-We did see a significant increase in cancer among men >60 years at diagnosis, so this subgroup might still merit surveillance.

-With progressive disease the cancer risk increases just as for any patient with kidney failure regardless of aetiology and regular cancer screening should be advocated, foremost in those of high age and in patients with a kidney transplant. 


\section{INTRODUCTION}

$\operatorname{IgA}$ nephropathy (IgAN) is the most common type of primary glomerulonephritis worldwide

(1). The clinical presentation varies from asymptomatic, mild disease to acute kidney injury, and progresses to end stage renal disease (ESRD) in 15 to $50 \%$ of the cases (2-4).

An association, mainly as a paraneoplastic phenomenon, between glomerular disorders and cancer has long been discussed (5-8). While a recent study supports such an association between glomerulonephritis and cancer (9), there are little data on overall cancer risk in IgAN. A few studies have reported an increased risk specifically of lymphoproliferative disease, kidney and lung cancer in patients with IgAN but these studies have been small or lacked reference groups (10-16).

The aim of this study was to examine the risk of any and site-specific cancers in a large nationwide population-based cohort of individuals with IgAN compared with matched reference individuals.

\section{MATERIALS AND METHODS}

\section{Exposure: Definition of IgAN}

In this cohort study we defined IgAN as having a record of a kidney biopsy confirming IgAN (diagnosed in 1974-2011) at any of the four pathology departments that evaluate kidney biopsies in Sweden (Stockholm, Gothenburg, Linköping, and Malmö/Lund). Patient charts were reviewed manually or ascertained by local IT departments that searched biopsy records for the IgAN Systematized Nomenclature of Medicine Clinical Term (SNOMED) code D67300 (17). Since this register was set up (18) a random subset of IgAN SNOMED codes has been manually validated by Jarrick et al. against patient charts and biopsy reports. They 
found a positive predictive value (PPV) of 95\% (95\% confidence interval (CI) 92-99\%) for the diagnosis (19).

\section{Outcome: Identifying cancer cases}

All permanent Swedish residents have a unique personal identity number (20). Through this we linked data on our IgAN patients to the Swedish Cancer Registry (21). More than $96 \%$ of all malignancies are reported to the Cancer Register each year and 99\% of all cancers are morphologically verified (21). Physicians reporting to the Cancer Register today report the International Classification of Diseases (ICD)-10 code and The Cancer Register then centrally supplements these data with the corresponding ICD-7 code(22). We have primarily used ICD7 codes for the analyses of overall cancer risk (codes listed in Appendix).

\section{Matched Reference Individuals}

The Total Population Register (23) is a register containing data on the birth, death, family, marital status, and migration of all Swedish citizens. Reference individuals, matched for age, sex, calendar year, and county of residence at the time of renal biopsy, were identified by the government agency Statistics Sweden. We used fiye reference individuals for each individual with IgAN.

There were no exclusion criteria pertaining to the control sampling except that the selected reference individuals had to be alive at the time of matching and not previously diagnosed with biopsy-verified $\operatorname{IgAN}$ at the time of matching of the index patient. Hence, our risk-set sampled reference individuals represent a random selection of the Swedish population including indiyiduals with and without other chronic diseases. 


\section{Covariates}

Diagnoses on smoking, tobacco use and/or chronic obstructive pulmonary disease (COPD) were assessed through relevant ICD codes in the National Patient Register (NPR) (listed in the Appendix) using the personal identity number. The NPR is a national register maintained by the National Board of Health and Welfare in Sweden. It contains data and diagnoses from all specialist medical care (hospitalization or non-primary care outpatient visits)(24). This information was used to adjust for smoking by proxy. Albeit this variable is probably incomplete with regards to smoking, we felt it important to control for smoking as an important risk factor for cancer development.

Data on highest educational level were obtained from the Swedish Longitudinal Integrated Database for Health Insurance and Labour Market Studies (LISA) (25). It was categorized according to length of education ( $\leq 9$ years compulsory school, 10-12 years, $\geq 13$ years/university and unknown). Education level is a proxy for socioeconomic status, which in turn is acknowledged as a risk factor for a number of other diseases. (26) We used the highest educational level available until the end of follow up, and in children we used their parents' level.

ESRD was defined as a clinical diagnosis of CKD 5, maintenance dialysis treatment and/or kidney transplantation (see Appendix for definition details).

\section{Exclusion criteria}

IgAN patients and reference individuals with a registered cancer in the Cancer Register before the kidney biopsy date and/or study start were excluded from the study. No other exclusion criterion was applied. 


\section{Follow-Up}

We defined the date of IgAN diagnosis as the day of the first kidney biopsy confirming IgAN.

Follow-up began at biopsy date and the corresponding date in the reference individuals.

Follow-up ended with cancer (event) or death, emigration or on the 31st of December 2015, whichever occurred first.

\section{Statistical Analyses}

We used Cox regression run in strata of each patient and its 5 matched (sex, age, calendaryear, and county) reference individuals. We further adjusted for smoking and educational attainment.

To assess reverse causation bias and also to evaluate $\operatorname{IgAN}$ as a paramalignant condition, we performed a sensitivity analysis where we started follow-up one year after IgAN diagnosis. Further, we also performed a Cox regression analysis with follow-up just for one year after the IgAN diagnosis.

To examine if the cancer risk was associated with kidney function, we divided the IgAN cohort further according to ESRD and transplantation status in three different analyses. One with patients that never reached ESRD or was diagnosed with cancer before reaching ESRD (i.e. date of ESRD was treated as an additional censoring event), one including only those who reached ESRD (using ESRD date as start of follow up for both IgAN cases and their matched reference individuals) and finally one analysis of those who underwent a kidney transplantation during follow up (similarly using the date of transplantation as start of follow up for both IgAN cases and reference individuals). The analysis restricted to those with a kidney transplant was motivated by the further increased risk of cancer in patients on immunosuppressive medication. In a sensitivity analysis we also analyzed the overall risk among ESRD patients who had not yet started dialysis treatment or had a kidney transplantation. 
Non-melanoma skin cancer (NMSC) is well known to occur in patients with ESRD and organ transplantation $(27,28)$, therefore we also analyzed cancer risk excluding NMSC in all subgroups.

Conditional logistic regression assessing the Odds Ratio (OR) of prior cancer diagnoses was performed comparing cases and reference individuals. In this analysis all patients from the original cohort and their reference individuals were included. The conditional logistic regressions were not run in strata, hence the analyses were adjusted for age, sex, calendaryear, county, proxy for smoking, and educational attainment.

\section{Ethics}

The study was approved by the Stockholm Ethics Review Board (22 January 2014, approval number: 2013/2095-31/2). Because this is a strictly register-based study, the requirement of informed consent was waived by the Board (29).

\section{RESULTS}

\section{Background data}

Our study cohort consisted of 3,882 patients with IgAN of which 1,117 (29\%) were women. Two thirds of the cohort were between $18-59$ years old, with approximately the same numbers in the age category $<18$ years as in $>60$ years. They were equally divided in the study entry year categories, and over $50 \%$ had a follow up period for more than 10 years. The majority $(76 \%)$ had an educational level higher than compulsory school (>9 years). In the IgAN cohort $85(2 \%)$ patients had a smoking or tobacco related record in the NPR, compared to $621(3 \%)$ of the reference individuals. Some $1,014(26 \%)$ of the patients with IgAN had or developed ESRD during follow up, and 793 (20\%) received a kidney transplant. 
Of the reference individuals 11 had ESKD at baseline, and another 33 developed ESRD during follow up. (see Table 1).

\section{Main results}

During a median follow-up of 12.6 years, 488 of 3,882 (13\%) patients with IgAN were diagnosed with cancer, compared to 1,783 of $19,341(9 \%)$ of the matched reference individuals, corresponding to an adjusted HR (aHR) of 1.68 (95\%CI 1.51-1.87).

Excluding the first year of follow up did not change the estimate considerably 1.70 (95\%CI 1.53-1.90), and with an aHR for any cancer during first year of follow-up being 1.41 (95\% CI 0.91-2.20).

Restricting the cancer diagnoses to all but non-melanoma skin cancer (NMSC) the association was weaker, but still statistically significant 1.31 (95\%CI 1.16-1.48). The risk was significantly increased in all subgroup analyses (male vs. female, different age-groups, and calendar years) except in the age category $<18$ years (see Table 2, Figure 1, and Supplementary table 1A-B).

Risk of cancer according to kidney function

In the non-ESRD subgroup, 265 of $3,534(7 \%)$ patients with IgAN developed a malignancy, compared to 1,779 of $19,330(9 \%)$ reference individuals, corresponding to an aHR of 1.13 (95\% CI 0.99-1.30), hence showing no difference between the IgAN patients and the reference individuals. (see Table 3. Figure 2, and Supplementary table 2).

In the ESRD group, 224 of 984 (23\%) patients with IgAN compared to 483 of 4,861 (10\%) reference individuals were diagnosed with cancer, resulting in an aHR of 4.01 (95\%CI 3.334.82), and when NMSC was excluded an aHR of 2.22 (95\%CI 1.79-2.75). (see Table 4, Fígure 3, and Supplementary table 3). 
Restricting the ESRD group to patients with a kidney transplant, the aHR was $4.46(95 \% \mathrm{CI}$ 3.64-5.46), while excluding NMSC yielded an aHR of 2.28 (95\%CI 1.80-2.88) (see Figure 4 and Supplementary tables 4 A-B).

Of the 327 patients who had not started dialysis treatment or undergone a kidney transplantation before ESRD diagnosis (based on ICD-coding), 12 (3.7\%) were diagnosed with cancer before starting dialysis or undergoing transplantation (aHR 2.26; 95\%CI 1.094.66).

\section{Incidence and Absolut excess risk}

In the main analysis we saw an incidence rate (IR) of 7.2 cases of cancer per 1,000 person years in the IgAN cohort when excluding NMSC, compared to 6.3 per 1,000 person years in the reference individuals. This corresponds to an absolute excess risk (AER) of 0.9 extra cases of cancer in the IgAN cohort. In the ESRD and kidney transplantation subgroups the IR was 14.0 and 13.6 cases of cancer per 1,000 person years, and the AER was 5.7 and 6.3 per 1,000 person years, respectively, for the IgAN patients.

\section{Site-specific cancers}

The site-specific cancer with the strongest association was by far NMSC in the ESRD and kidney transplantation subgroups, respectively. Excluding NMSC almost halved the excess risk in those subgroups, from aHR 4.01 (95\% CI 3.33-4.82) to aHR 2.22 (95\%CI 1.79-2.75) in the ESRD subgroup, and from aHR 4.46 (95\%CI 3.64-5.46) to aHR 2.28 (95\%CI 1.80-2.88) in the kidney transplantation group. In the main analysis the difference when excluding NMSC was not of the same magnitude.

Besides NMSC, cancer in the oral cavity, vulva/vagina, renal/uroepithelial, endocrine glands, colorectal and lymphoproliferative malignancies were the subtypes with the highest HR in both the ESRD and kidney transplantation subgroups. Restricting the analysis to kidney 
cancer alone, the aHR in the ESRD subgroup was 11.12 (95\%CI 4.60-26.91), compared to 1.65 (95\%CI 0.74-3.67) in non-ESRD patients. Cancer of the vulva/vagina was statistically significant in the main analysis, but since all 5 cancer cases in patients with IgAN were in the kidney transplantation strata, and the 6 cases in the control group were from individuals matched to patients in the non-ESRD it was not possible to calculate an aHR according to subgroups.

In ESRD patients who never started dialysis treatment or received a kidney transplant, the only site-specific cancer statistically significantly linked to IgAN was NMSC (aHR 7.57; $95 \%$ $1.26-45.44)$.

The cancer subtypes with the highest AER were NMSC (14.0 and 15.7 per 1,000 person years) renal/uroepithelial (1.7 and 1.7 per 1,000 person years), colorectal (1.2 and 1.4 per 1,000 person years) and cancer in the oral cavity ( 0.8 and 0.9 per 1,000 person years) in both ESRD and kidney transplantation subgroups, respectively,

Non-ESRD patients did not have an increased risk of any cancer (aHR 1.13, 95\%CI 0.991.30), but had a significantly higher risk of NMSC (aHR 1.90; 95\%CI 1.29-2.79), and further for prostate and renal/uroepithelial cancer.

(see Table 2-4, Figures 1-4, and Supplementary table 4A)

Risk of having a cancer diagnosis before IgAN

Of the study start IgAN cohort of 4,037 a total of $155(4 \%)$ had a cancer diagnosis before their IgAN was confirmed. In the reference individuals the number was 707 of 20,048 (4\%). The conditional logistics regression showed an adjusted OR of 1.10 (95\%CI 0.92-1.32), indicating that there was no increased risk of cancer for the IgAN cohort. (see Supplementary Table 5) 


\section{DISCUSSION}

In this study we found no support for an increased risk of cancer prior to an IgAN diagnosis or for IgAN being a paramalignant condition. We did find an increased risk of cancer in IgAN patients but confined only to those with ESRD. There was a slight risk increase in those with ESRD without dialysis treatment or transplantation (aHR 2.26), although higher than for those who never developed ESRD (aHR 1.13). The risk increase was especially high in patients who had undergone a kidney transplantation (aHR 4.46).

\section{Comparison to other studies}

The association between cancer and glomerulonephritis has been widely discussed and several malignancies have been suggested to be associated with IgAN as paramalignant condition. Most often mentioned is renal cell carcinoma(11,14,30), but also lung cancer (13), larynx (10), esophagus (31), and lymphomas (12,16,32,33). Furthermore, Mustonen et al suggest a possible connection between mucosal affection of solid tumors in respiratory, buccal cavity and nasopharynx with higher circulating IgA-levels causing IgA depositions in the kidney (10). Most of these studies are small or consist of case reports lacking statistical power, and in contrast to what these and other studies have implied $(5-9,34)$ we did not see a paramalignant pattern in patients with $\operatorname{IgAN}$ and a cancer diagnosis. Most of the cancer diagnoses in our study were not in direct temporal connection with the IgAN diagnosis, nor was there a higher rísk of having a cancer diagnosis before the kidney disease. This also partly contrasts to a more recent study by Ryu et al (9). These researchers analyzed 1,155 patients with biopsy-verified glomerulonephritis and found an almost three times higher (O/E-ratio $3.42 ; 95 \%$ CI 1.37-5.46) risk for cancer within a month after their kidney diagnosis in patients aged $>50$ years compared to the general population, although, in their IgAN subgroup they had only 3 cases of cancer in 438 patients and could not confirm a statistically significant 
association. Heaf et al (34) also examined cancer incidence in patients with biopsy proven glomerulonephritis. They found 911 cancer events in 5,594 patients, with an increased risk of cancer mainly 1 year before or after a glomerulonephritis diagnosis. In that study IgAN patients were not specifically studied but included in a group with more uncommon types of glomerulonephritis, hence the results cannot be completely extrapolated to the IgAN cohort.

Even if potentially not being a paramalignant condition, our results showed an increased risk of cancer in IgAN patients, but only for patients who progressed to ESRD, especially for NMSC and kidney cancer. These elevated risks and sites of cancer in patients with kidney failure is consistent with several previous studies (35-39) and may indicate increased cancer risk regardless of aetiology (40-48). Further supporting that cancer risk increases with function failure rather than within a specific aetiology of the kidney disorder, $\mathrm{Xu}$ et al examined the correlation between cancer risk and creatinine levels as a part of the Stockholm creatinine Measurements (SCREAM) project. The project included ereatinine information from 719,033 individuals $>40$ years without previous records of cancer. They identified 64,319 cancer events (in $9 \%$ of the participants) which revealed a U-shaped association between kidney function loss and risk of cancer. Xu et al association was modest in magnitude, and primarily driven by NMSC and urogenital cancers. They concluded that detection bias and/or reverse causation could partly explain an overestimation of the increased risk of cancer in patients with CKD, especially during the first year of follow-up (48).

In more aggressive and rapidly progressive forms of $\operatorname{IgAN}$, that more often end in terminal kidney failuré, carcinogenic immunosuppressive medications e.g. cyclophosamide or azathioprine are commonly used (49), and all patients with a kidney transplant will be on multiple immunosuppression regimes. This epidemiological study cannot conclude anything on causality, and we did not have sufficient data to explore the impact of kidney medications 
more accurately on cancer risk, although we believe that immunosuppression is the main reason for the increased risk in the ESRD/kidney transplantation group.

In our study we did not find a statistically significant association between IgAN and overall cancer in patients with non-ESRD, except for prostate cancer, renal/uroepithelial cancer and NMSC in men $>60$ years. This is probably due to detection bias, because of the more frequent health care visits in the IgAN group, and that the disorder will also more often implicate ultrasounds of the kidneys and screening of postrenal obstructions.

There were no major differences in cancer risk or specific cancer subtypes between the ESRD group and those who underwent a kidney transplantation, which is probably explained by the fact that approximately $80 \%$ (793 of 1,014) of the ESRD population were transplanted. The cancer subtypes with the strongest association were NMSC, renal/uroepithelial (most distinctive kidney cancer), vulva/vagina, cancer in the oral cavity, endocrine glands, colorectal, and lymphoproliferative malignancies, and this is consistent with several other studies on cancer risk post-kidney transplantation. Our results are fairly similar to those of a recent study by Benoni et al examining cancer incidence in patients from the Nordic countries receiving a kidney transplantation (50).

\section{Strengths and Limitations}

The main strengths of our study are the large cohort of well-characterized individuals and very long follow-up with a median of 12.6 years. We believe this is the largest study to date examining $\operatorname{IgA}$ and cancer. Through the unique personal identity number, we were able to follow-up patients and reference individuals without virtually no loss of follow-up. Further, The Cancer Registry is highly used, validated and with almost complete coverage of all cancers in Sweden. 
A limitation in our study could be that it is constrained to patients with biopsy-verified IgAN.

However, the fact that approximately one third of our patients were women, and $26 \%$ of the IgAN population progressed to ESRD (both proportions consistent with the expected (2)) suggest that our cohort is representative of the average IgAN patient, with a low risk of selection bias.

While our study is representative of the Swedish population, which is predominantly of Caucasian ethnicity, we call for caution when extrapolating of our findings to other countries or ethnically diverse societies. Our ascertainment for smoking from clinical diagnoses is not complete, but we still believe it adds important data on confounding. Nor have we adjusted for other comorbidities or medications.

Finally, there is a risk of detection bias because patients with IgAN are likely to visit healthcare more frequently than the general population, although the main findings were that the non-ESRD patients did not seem to have a higher risk for cancer, or that IgAN is to be considered a paramalignant condition. This lack of association with cancer was further supported in the sensitivity analysis when we excluded the first year of follow up and got almost exactly the same estimate as in the main analysis.

\section{Implication of the findings}

That IgAN does not seem to imply a higher risk of cancer, supports the current KDIGO guidelines (49) that cancer screening is not needed in the average patient with IgAN. However, we did see a significant increase in cancer among men $>60$ years at diagnosis, so this subgroup might still merit surveillance. And with progressive disease the risk increases just as for any patient with kidney failure regardless of aetiology.

In patients with progressive disease and terminal kidney failure, especially those of high age, regular cancer screening should be advocated and directed questions recorded systematically 
in patients' medical charts to improve chances of an early detection of any future malignant condition. Skin cancer surveillance should be performed routinely, that is especially importantly after a kidney transplantation since NMSC can metastasize in patients with immunosuppression (27). Our results indicate approximately 6 extra cancer case per 100 IgAN patients with ESRD per 10 years, or $>17$ extra cases if including NMSC as well.

\section{Conclusion}

We found no support for a higher risk of cancer prior to an IgAN diagnosis, or for IgAN being a paramalignant condition. We found an increased risk for cancer in patients with IgAN, but this excess risk was confined only to those who developed ESRD. The risk was foremost increased in patients with a kidney transplant. The association is not interpreted to be IgAN specific, but possibly secondary to kidney function loss and immunosuppression.

\section{AUTHORS' CONTRIBUTIONS}

J.R, J.F.L and L.E designed the study. J.R and L.E analyzed the data. J.R made the tables, figure and drafted the paper, with inputs from L.E, J-J.C and J.F.L. L.E supervised the study. All the authors approved the final version of the manuscript. The corresponding author (LE) had full access to all the data in the study and had final responsibility for the decision to submit for publication.

\section{CONFLICT OF INTEREST STATEMENT}

Dr Ludvigsson coordinates a study on behalf of the Swedish IBD quality register (SWIBREG) and that study has received funding from Janssen corporation. 


\section{FUNDING}

Dr Rehnberg has funding from County Council of Värmland, Sweden. The sponsor had no role in the study design; data collection; data analysis; and interpretation of data; writing of the report; and the decision to submit the paper for publication. JJC acknowledges support from the Swedish Research Council (2019-01059). 


\section{REFERENCES}

1. D'Amico G. The commonest glomerulonephritis in the world: IgA nephropathy. Quarterly Journal of Medicine. 1987.

2. Donadio J V., Grande JP. IgA nephropathy. New England Journal of Medicine. 2002.

3. D'Amico G. Natural history of idiopathic IgA nephropathy and factors predictive of disease outcome. Semin Nephrol. 2004;

4. Wyatt RJ, Julian BA. MEdical progress: IgA nephropathy. New England Journal of Medicine. 2013.

5. Lee JC, Yamauchi H, Hopper J. The association of cancer and the nephrotic syndrome. Ann Intern Med. 1966;

6. Lien YHH, Lai LW. Pathogenesis, diagnosis and management of paraneoplastic glomerulonephritis. Nature Reviews Nephrology. 2011.

7. Pani A, Porta C, Cosmai L, Melis P, Floris M, Piras D, et al. Glomerular diseases and cancer: evaluation of underlying malignancy. Journal of Nephrology. 2016.

8. Ronco PM. Paraneoplastic glomerulopathies: New insights into an old entity. Kidney Int. 1999;

9. Ryu J, Ryu HJ, Kim S, Chin HJ, Na KY, Chae DW, et al. Comparison of cancer prevalence between patients with glomerulonephritis and the general population at the time of kidney biopsy. PLoS One. 2019;

10. Mustonen J, Pasternack A, Helin H. IgA mesangial nephropathy in neoplastic diseases. Contrib Nephrol. 1984;

11. Magyarlaki T, Kiss B, Buzogány I, Fazekas A, Sükösd F, Nagy J, Renal cell carcinoma and paraneoplastic IgA nephropathy. Nephron. 1999;

12. Cherubini C, Barbera G, Di Giulio S, Muda AO, Faraggiana T. Lymphomas and IgA nephropathy [4]. Nephrology Dialysis Transplantation. 2001.

13. Paraneoplastic IgA nephritis as initial symptom of a bronchial carcinoma. Lung Cancer. 1997;

14. Mimura I, Tojo A, Kinugasa S, Uozaki H, Fujita T. Renal cell carcinoma in association with IgA nephropathy in the elderly. Am J Med Sci. 2009;

15. Motoyama O, Kojima Y, Ohara A, Tsukimoto I, Ishikawa Y, Iitaka K. IgA nephropathy associated with leukemia and lymphoma: Report of two cases. Clin Exp Nephrol. 2008;

16. Bajel A, Yin Lin M, Hill PA, Goodman D, McCormack C, Foley P, et al. IgA nephropathy associated with cutaneous $\mathrm{T}$ cell lymphoma. Leukemia and Lymphoma. 2009.

17. SNOMED International:SNOMED CT, Swedish Edition v1.37.3, 2018. Available at:http://browser.ihtsdotools.org/index-

ie. $h$ tml?perspective $=$ full\&conceptId $1=404684003 \&$ edition $=$ se -

edition\&release $=\mathrm{v} 20180531 \&$ server=https://prod-browser-exten.ihtsdotools.org/api/s.

18. Welander A, Sundelin B, Fored M, Ludvigsson JF. Increased risk of IgA nephropathy among individuals with celiac disease. J Clin Gastroenterol. 2013;

19. Jarrick S, Lundberg S, Welander A, Fored CM, Ludvigsson JF. Clinical validation of immunoglobulin A nephropathy diagnosis in Swedish biopsy registers. Clin Epidemiol. 2017;

20. Ludvigsson JF, Otterblad-Olausson P, Pettersson BU, Ekbom A. The Swedish personal identity number: Possibilities and pitfalls in healthcare and medical research. Eur J Epidemiol. 2009; 
21. Barlow L, Westergren K, Holmberg L, Tälback M. The completeness of the Swedish Cancer Register - A sample survey for year 1998. Acta Oncol (Madr). 2009;

22. Socialstyrelsen. Cancer incidence in Sweden 2005. Statistics: Health and Diseases 2007:3. Stockholm, 2007.

23. Ludvigsson JF, Almqvist C, Bonamy AKE, Ljung R, Michaëlsson K, Neovius M, et al. Registers of the Swedish total population and their use in medical research. Eur J Epidemiol. 2016;

24. Ludvigsson JF, Andersson E, Ekbom A, Feychting M, Kim JL, Reuterwall C, et al. External review and validation of the Swedish national inpatient register. BMC Public Health. 2011;

25. Ludvigsson JF, Svedberg P, Olén O, Bruze G, Neovius M. The longitudinal integrated database for health insurance and labour market studies (LISA) and its use in medical research. European Journal of Epidemiology. 2019.

26. Olén O, Bihagen E, Rasmussen F, Ludvigsson JF. Socioeconomic position and education in patients with coeliac disease. Dig Liver Dis. 2012;

27. Grulich AE, Vajdic CM. The epidemiology of cancers in human immunodeficiency virus infection and after organ transplantation. Seminars in Oncology. 2015.

28. Krynitz B, Edgren G, Lindelöf B, Baecklund E, Brattström C, Wilczek H, et al. Risk of skin cancer and other malignancies in kidney, liver, heart and lung transplant recipients 1970 to 2008 - A Swedish population-based study. Int J Cancer. 2013;

29. Ludvigsson JF, Håberg SE, Knudsen GP, Lafolie P, Zoega H, Sarkkola C, et al. Ethical aspects of registry-based research in the Nordic countries. Clinical Epidemiology. 2015.

30. Tanaka K, Kanzaki H, Taguchi T. IgA glomerulonephritis in a patient with renal cell carcinoma. Japanese J Nephrol. 1991;

31. Lam KY, Law SYK, Chan KW, Yuen MC. Glomerulonephritis associated with basaloid squamous cell carcinoma of the oesophagus: A possible unusual paraneoplastic syndrome. Scand J Urol Nephrol. 1998;

32. Moe SM, Baron JM, Coventry S, Dolan C, Umans JG. Glomerular Disease and Urinary Sézary Cells in Cutaneous T-Cell Lymphomas. Am J Kidney Dis. 1993;

33. Zahner J, Bach D, Malms J, Schneider W, Diercks K, Grabensee B. [Glomerulonephritis and malignant lymphoma. Mostly men with low-grade lymphoma with various forms of glomerulonephritis]. Med Klin. 1997;

34. Heaf JG, Hansen A, Laier GH. Quantification of cancer risk in glomerulonephritis. BMC Nephrol. 2018;

35. Matas AJ, Kjellstrand CM, Simmons RL, Buselmeier TJ, Najarian JS. INCREASED INCIDENCE OF MALIGNANCY DURING CHRONIC RENAL FAILURE. Lancet. 1975;

36. Cengiz K. Increased incidence of neoplasia in chronic renal failure (20-year experience). Int Urol Nephrol. 2002;

37. Vajdic CM, McDonald SP, McCredie MRE, Van Leeuwen MT, Stewart JH, Law M, et al. Cancer incidence before and after kidney transplantation. J Am Med Assoc. 2006;

38. Mok Y, Matsushita K, Ballew SH, Sang Y, Jung KJ, Lee S, et al. Kidney Function, Proteinuria, and Cancer Incidence: The Korean Heart Study. Am J Kidney Dis. 2017;

39. Wong G, Hayen A, Chapman JR, Webster AC, Jie JW, Mitchell P, et al. Association of CKD and cancer risk in older people. J Am Soc Nephrol. 2009; 
40. Tonelli M, Sacks F, Pfeffer M, Jhangri GS, Curhan G. Biomarkers of inflammation and progression of chronic kidney disease. Kidney Int. 2005;

41. Coussens LM, Werb Z. Inflammation and cancer. Nature. 2002.

42. Viazzi F, Bonino B, Cappadona F, Pontremoli R. Renin-angiotensin-aldosterone system blockade in chronic kidney disease: current strategies and a look ahead. Internal and Emergency Medicine. 2016.

43. Ager EI, Neo J, Christophi C. The renin-angiotensin system and malignancy. Carcinogenesis. 2008 .

44. Franses JW, Drosu NC, Gibson WJ, Chitalia VC, Edelman ER. Dysfunctional endothelial cells directly stimulate cancer inflammation and metastasis. Int J Cancer. 2013;

45. González EA, Sachdeva A, Oliver DA, Martin KJ. Vitamin D Insufficiency and Deficiency in Chronic Kidney Disease. Am J Nephrol. 2004;

46. Vandewalle B, Adenis A, Hornez L, Revillion F, Lefebvre J. 1,25-Dihydroxyvitamin D3 receptors in normal and malignant human colorectal tissues. Cancer Lett. 1994;

47. Mawer EB, Walls J, Howell A, Davies M, Ratcliffe WA, Bundred NJ. Serum 1,25 dihydroxyvitamin $\mathrm{D}$ may be related inversely to disease activity in breast cancer patients with bone metastases. J Clin Endocrinol Metab. 1997;

48. Xu H, Matsushita K, Su G, Trevisan M, Ärnlöv J, Barany P, et al. Estimated glomerular filtration rate and the risk of cancer. Clin J Am Soc Nephrol. 2019;

49. Kidney Disease Improving Global Outcomes. KDIGO Clinical practice guideline for glomerulonephritis. Kidnet Int Suppl. 2012;

50. Benoni H, Eloranta S, Dahle DO, Svensson MHS, Nordin A, Carstens J, et al. Relative and absolute cancer risks among Nordic kidney transplant recipients - a population-based study. Transpl Int. 2020; 
Table 1. Baseline characteristics

\begin{tabular}{|c|c|c|}
\hline Participant characteristics & $\begin{array}{l}\text { IgAN } \\
\text { n }(\%)\end{array}$ & $\begin{array}{c}\text { Controls } \\
\text { n }(\%)\end{array}$ \\
\hline Total & $3,882(100)$ & $19,341(100)$ \\
\hline \multicolumn{3}{|l|}{ Matched variables } \\
\hline \multicolumn{3}{|l|}{ Sex } \\
\hline Female & $1,117(29)$ & $5,508(29)$ \\
\hline Male & $2,765(71)$ & $13,833(71)$ \\
\hline \multicolumn{3}{|l|}{ Age (years) } \\
\hline$<18$ & $373(10)$ & $1,866(10)$ \\
\hline $18-39$ & $1,654(43)$ & $8,244(43)$ \\
\hline $40-59$ & $1,337(34)$ & $6,632(34)$ \\
\hline$\geq 60$ & $518(13)$ & $2,599(13)$ \\
\hline \multicolumn{3}{|l|}{ Calendar year } \\
\hline \multicolumn{3}{|l|}{ Entry year } \\
\hline 1974-1994 & $1,037(27)$ & $5,131(27)$ \\
\hline 1995-2005 & $1,614(42)$ & $8,067(42)$ \\
\hline $2006-2015$ & $1,231(32)$ & $6,143(32)$ \\
\hline \multicolumn{3}{|l|}{ Unmatched Variables } \\
\hline \multicolumn{3}{|l|}{ Follow-up (years) } \\
\hline Mean $(\mathrm{SD})$ & $12.8(8.3)$ & $13.6(8,4)$ \\
\hline$<1$ & $80(2)$ & $240(1)$ \\
\hline $1-5$ & $596(15)$ & $2,705(14)$ \\
\hline $5-10$ & $1,020(26)$ & $4,689(24)$ \\
\hline$\geq 10$ & $2,186(56)$ & $11,707(61)$ \\
\hline \multicolumn{3}{|l|}{ Educational level } \\
\hline Compulsory school, $\leq 9$ years & $844(22)$ & $4,102(21)$ \\
\hline Upper secondary school, $1-3$ years & $1,716(44)$ & $8,690(45)$ \\
\hline University level & $1,228(32)$ & $6,095(32)$ \\
\hline Unknown & $94(2)$ & $454(2)$ \\
\hline Smokers/COPD diagnosis & $85(2)$ & $621(3)$ \\
\hline \multicolumn{3}{|l|}{ Kidney function } \\
\hline End stage renal disease at baseline & $348(9)$ & $11(0.1)$ \\
\hline $\begin{array}{l}\text { End stage renal disease during } \\
\text { follow up }\end{array}$ & $666(17)$ & $33(0.2)$ \\
\hline $\begin{array}{l}\text { Kidney transplantation during } \\
\text { follow up }\end{array}$ & $793(20)$ & $15(0.1)$ \\
\hline
\end{tabular}

IgAN: IgA nephropathy

SD: Standard deviation

COPD: chronic obstructive pulmonary disease 


\begin{tabular}{|c|c|c|c|c|c|c|c|c|c|c|}
\hline & IgAN & Controls & $\begin{array}{l}\text { Cancer } \\
\text { events } \\
\text { IgAN }\end{array}$ & $\begin{array}{c}\text { Cancer } \\
\text { events } \\
\text { Controls }\end{array}$ & \begin{tabular}{|c} 
Follow up \\
years \\
IgAN \\
\end{tabular} & \begin{tabular}{|c|} 
Follow up \\
years \\
Controls \\
\end{tabular} & $\begin{array}{l}\text { IR IgAN } \\
(95 \% \text { CI }) \\
\end{array}$ & $\begin{array}{l}\text { IR Controls } \\
(95 \% \text { CI })\end{array}$ & $\begin{array}{c}\text { HR } \\
(95 \% \mathrm{CI}) \\
\end{array}$ & 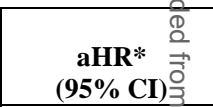 \\
\hline Any_cancer & $\begin{array}{l}3882 \\
(100 \%)\end{array}$ & $\begin{array}{l}19341 \\
(100 \%)\end{array}$ & $488(12.6 \%)$ & $1783(9.2 \%)$ & 49852 & 262834 & 9.8 (8.9-10.7) & $6.8(6.5-7.1)$ & $1.68(1.51-1.87)$ & $1.70\left(1.52-1.8 \frac{\sqrt{9}}{9}\right)$ \\
\hline $\begin{array}{l}\text { Any cancer, not } \\
\text { NMSC }\end{array}$ & \begin{tabular}{|l|}
3897 \\
$(100 \%)$ \\
\end{tabular} & \begin{tabular}{|l|}
19371 \\
$(100 \%)$
\end{tabular} & $366(9.4 \%)$ & $1666(8.6 \%)$ & 50828 & 263899 & $7.2(6.5-7.9)$ & $6.3(6.0-6.6)$ & $1.30(1.16-1.47)$ & 1.31 (1.16-1.48) \\
\hline & & & & & & & & & & $\frac{0}{\frac{0}{3}}$ \\
\hline Oral cavity & \begin{tabular}{|l|}
4034 \\
$(100 \%)$
\end{tabular} & $\begin{array}{l}20039 \\
(100 \%)\end{array}$ & $19(0.5 \%)$ & $36(0.2 \%)$ & 53769 & 279351 & $0.4(0.2-0.5)$ & $0.1(0.1-0.2)$ & $2.84(1.59-5.06)$ & $2.83(1.58-5.03)$ \\
\hline Solid & $\begin{array}{l}3890 \\
(100 \%)\end{array}$ & $\begin{array}{l}19372 \\
(100 \%)\end{array}$ & $472(12.1 \%)$ & $1676(8.7 \%)$ & 50022 & 263607 & $9.4(8.6-10.3)$ & $6.4(6.1-6.7)$ & $1.73(1.55-1.93)$ & $1.74\left(1.56-1.9 \frac{9}{2}\right)$ \\
\hline Hematological & $\begin{array}{l}4025 \\
(100 \%)\end{array}$ & $\begin{array}{l}20015 \\
(100 \%)\end{array}$ & $31(0.8 \%)$ & $148(0.7 \%)$ & 53731 & 278683 & $0.6(0.4-0.8)$ & $0.5(0.4-0.6)$ & $1.31(0.88-1.96)$ & $1.34(0.90-2.09$ \\
\hline Lymphoproliferative & $\begin{array}{l}4029 \\
(100 \%)\end{array}$ & $\begin{array}{l}20020 \\
(100 \%)\end{array}$ & $23(0.6 \%)$ & $122(0.6 \%)$ & 53778 & 278822 & $0.4(0.3-0.6)$ & $0.4(0.4-0.5)$ & $1.23(0.7$ & $1.27\left(0,80-2.0 \frac{0}{20}\right)$ \\
\hline GI-tract & $\begin{array}{l}4017 \\
(100 \%)\end{array}$ & $\begin{array}{l}19971 \\
(100 \%)\end{array}$ & $76(1.9 \%)$ & $361(1.8 \%)$ & 53584 & 277882 & $1.4(1.1-1.7)$ & $1.3(1.2-1.4)$ & $1.24(0.96-1.61)$ & 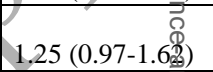 \\
\hline Gastric & $\begin{array}{l}4037 \\
(100 \%)\end{array}$ & $\begin{array}{l}20041 \\
(100 \%)\end{array}$ & $6(0.1 \%)$ & $43(0.2 \%)$ & 53928 & 279479 & $0.1(0.0-0.2)$ & $0.2(0.1-0.2)$ & $0.73(0.31-1.75)$ & $0.70\left(0.29-1.6 \frac{\overline{\bar{N}}}{2}\right.$ \\
\hline Colorectal & $\begin{array}{l}4018 \\
(100 \%)\end{array}$ & $\begin{array}{l}19988 \\
(100 \%)\end{array}$ & $52(1.3 \%)$ & $217(1.1 \%)$ & 53622 & 278194 & $1.0(0.7-1.2)$ & $0.8(0.7-0.9)$ & $1.44(1.05-1.97)$ & $1.46\left(1.06-2.00 \frac{0}{0}\right.$ \\
\hline Liver & $\begin{array}{l}4037 \\
(100 \%)\end{array}$ & $\begin{array}{l}20048 \\
(100 \%)\end{array}$ & $7(0.2 \%)$ & $29(0.1 \%)$ & 53936 & 279547 & $0.1(0.0-0.2)$ & ( & $(0.62-3.42)$ & $1.88(0.77-4.5 \overrightarrow{8}$ \\
\hline Pancreas & $\begin{array}{l}4037 \\
(100 \%)\end{array}$ & $\begin{array}{l}20047 \\
(100 \%)\end{array}$ & $5(0.1 \%)$ & $52(0.3 \%)$ & 53931 & 279543 & $0.1(0.0-0.2)$ & $0.2(0.1-0.2)$ & $0.61(0.24-1.56)$ & $0.54\left(0.21-1.4 \stackrel{\frac{\omega}{\partial}}{\vec{\rho}}\right)$ \\
\hline Lung & $\begin{array}{l}4034 \\
(100 \%)\end{array}$ & $\begin{array}{l}20039 \\
(100 \%)\end{array}$ & $8(0.2 \%)$ & $117(0.6 \%)$ & 53911 & 279355 & $0.1(0.0-0.3)$ & $0.4(0.3-0.5)$ & $0.43(0.21-0.89)$ & 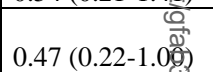 \\
\hline Breast & \begin{tabular}{|l|}
1169 \\
$(29.0 \%)$
\end{tabular} & \begin{tabular}{|l|}
5781 \\
$(28.9 \%)$
\end{tabular} & $21(1.8 \%)$ & $152(2.6 \%)$ & 16028 & 80085 & $1.3(0.7-1.9)$ & $1.9(1.6-2.2)$ & $0.71(0.44-1.12)$ & $\begin{array}{r}\frac{N}{N} \\
0.70(0.44-1.12\end{array}$ \\
\hline Upper airways & \begin{tabular}{|l|}
4034 \\
$(100 \%)$
\end{tabular} & $\begin{array}{l}20043 \\
(100.0 \%)\end{array}$ & $3(0.1 \%)$ & $13(0.1 \%)$ & 53879 & 279515 & $0.1(0.0-0.1)$ & $0.0(0.0-0.1)$ & $1.36(0.37-4.96)$ & $2.96(0.65-13.49)$ \\
\hline Prostate & \begin{tabular}{|l|}
2840 \\
$(70.7 \%)$
\end{tabular} & $\begin{array}{l}14092 \\
(70.6 \%)\end{array}$ & $95(3.3 \%)$ & $442(3.1 \%)$ & 37114 & 194621 & & $2.3(2.1-2.5)$ & $1.40(1.11-1.77)$ & $1.42(1.13-1.8 \overline{6})$ \\
\hline Renal/Urinary & \begin{tabular}{|l|}
4027 \\
$(100 \%)$
\end{tabular} & $\begin{array}{l}20004 \\
(100 \%)\end{array}$ & $52(1.3 \%)$ & $144(0.7 \%)$ & 53680 & 278 & $1.0(0.7-1.2)$ & $0.5(0.4-0.6)$ & $2.22(1.58-3.12)$ & 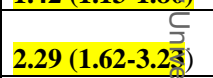 \\
\hline Nervous system & \begin{tabular}{|l|}
4032 \\
$(100 \%)$
\end{tabular} & $\begin{array}{l}20018 \\
(100 \%)\end{array}$ & $13(0.3 \%)$ & $49(0.2 \%)$ & 53796 & 278995 & $0.2(0.1-0.4)$ & $0.2(0.1-0.2)$ & $1.38(0.74-2.58)$ & $1.40\left(0.74-2.6 \frac{0}{3)}\right.$ \\
\hline Endocrine glands & $\begin{array}{l}4027 \\
(100 \%)\end{array}$ & $\begin{array}{l}20025 \\
(100 \%)\end{array}$ & $14(0.3 \%)$ & $43(0.2 \%)$ & 53776 & 279055 & $0.3(0.1-0.4)$ & $0.2(0.1-0.2)$ & $1.65(0.89-3.05)$ & $1.66(0.89-3.0 \%$ \\
\hline Penis/Testis & \begin{tabular}{|l|}
2856 \\
$(70.8 \%)$ \\
\end{tabular} & $\begin{array}{l}14165 \\
(70.7 \%)\end{array}$ & $2(0.1 \%)$ & $16(0.1 \%)$ & $3 / 6 / 1$ & 197156 & $0.1(0.0-0.1)$ & $0.1(0.0-0.1)$ & $0.81(0.18-3.60)$ & $0.79\left(0.17-3.6 \frac{5}{3}\right)$ \\
\hline Vulva/Vagina & \begin{tabular}{|l|}
1176 \\
$(29.1 \%)$
\end{tabular} & $\begin{array}{l}5858 \\
(29.2 \%)\end{array}$ & $5(0.4 \%)$ & $6(0.1 \%)$ & & 81952 & $0.3(0.0-0.6)$ & $0.1(0.0-0.1)$ & $3.79(1.15-12.50)$ & $3.80(1.13-12.78)$ \\
\hline Cervix/Uterus/Ovaries & \begin{tabular}{|l|}
1139 \\
$(28.5 \%)$
\end{tabular} & $\begin{array}{l}5653 \\
(28.5 \%)\end{array}$ & $21(1.8 \%)$ & 7 & 2. & 78005 & $1.3(0.8-1.9)$ & $1.8(1.5-2.1)$ & $0.74(0.47-1.18)$ & $0.72(0.45-1.1$ 画 $)$ \\
\hline Melanoma & \begin{tabular}{|l|}
4029 \\
$(100 \%)$
\end{tabular} & $\begin{array}{l}20004 \\
(100 \%)\end{array}$ & $35(0.9 \%)$ & $140(0.7 \%)$ & 53652 & 278191 & $0.7(0.4-0.9)$ & $0.5(0.4-0.6)$ & $1.40(0.95-2.04)$ & $1.36(0.92-2.0 \hat{0}$ \\
\hline Skeleton & $\begin{array}{l}4036 \\
(100 \%)\end{array}$ & $\begin{array}{l}20043 \\
(100 \%)\end{array}$ & $1(0.0 \%)$ & $(0.0 \%)$ & 53926 & 279513 & $0.0(0.0-0.1)$ & $0.0(0.0-0.0)$ & $5.00(0.31-79.95)$ & $3.00(0.19-47 . \stackrel{\vec{D}}{\stackrel{8}{0} 6)}$ \\
\hline Skin & \begin{tabular}{|l|}
4019 \\
$(100 \%)$
\end{tabular} & $\begin{array}{l}20011 \\
(100 \%)\end{array}$ & $178(4.4 \%)$ & $185(0.9 \%)$ & 52728 & 278221 & $3.4(2.9-3.9)$ & $0.7(0.6-0.8)$ & $6.87(5.42-8.72)$ & $6.87(5.40-8.79)$ \\
\hline $\begin{array}{l}\text { Ig } \\
\mathrm{HF} \\
\mathrm{CI} \\
\text { IR }\end{array}$ & $\begin{array}{l}\mathrm{N}: \operatorname{IgA} \\
\text { : Hazar } \\
\text { Confid } \\
\text { Incider }\end{array}$ & $\begin{array}{l}\text { nephro } \\
\text { rd Ratio } \\
\text { dence in } \\
\text { nce rate }\end{array}$ & $\begin{array}{l}\text { opathy } \\
\text { terval } \\
\text { per } 1,00 \\
\text { strata of } \\
\text { ted for sr }\end{array}$ & $\begin{array}{l}\text { erson y } \\
\text { ancer } \\
\text { es and } 5 \\
\text { king anc }\end{array}$ & ducat & atta & ent & $10.10 .00 .0)$ & 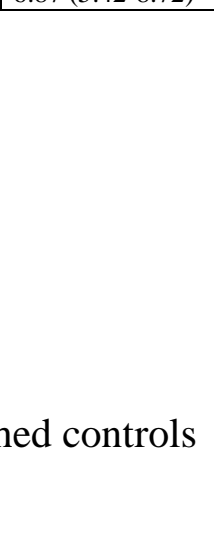 & 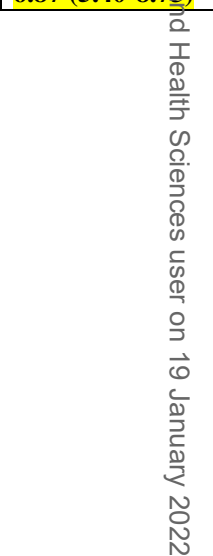 \\
\hline
\end{tabular}




\begin{tabular}{|c|c|c|c|c|c|c|c|c|c|c|}
\hline Subgroups cancer & IgAN & Controls & $\begin{array}{c}\text { Cancer } \\
\text { events IgAN }\end{array}$ & \begin{tabular}{|c|} 
Cancer events \\
Controls
\end{tabular} & \begin{tabular}{|c}
$\begin{array}{c}\text { Follow up } \\
\text { years } \\
\text { IgAN }\end{array}$ \\
\end{tabular} & $\begin{array}{c}\text { Follow up } \\
\text { years } \\
\text { Controls } \\
\end{array}$ & $\begin{array}{l}\text { IR IgAN } \\
(95 \% \mathrm{CI}) \\
\end{array}$ & $\begin{array}{c}\text { IR Controls } \\
(95 \% \mathrm{CI})\end{array}$ & $\begin{array}{c}\text { HR } \\
(95 \% \mathrm{CI}) \\
\end{array}$ & 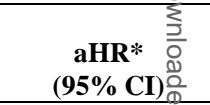 \\
\hline Any_cancer & $\begin{array}{l}3534 \\
(100 \%)\end{array}$ & $\begin{array}{l}19330 \\
(100 \%)\end{array}$ & $265(7.5 \%)$ & $1779(9.2 \%)$ & 41342 & 262623 & $6.4(5.6-7.2)$ & $6.8(6.5-7.1)$ & $1.13(0.98-1.30)$ & $1.13(0.99-1.3 \underline{\underline{\vec{\theta}}})$ \\
\hline $\begin{array}{l}\text { Any cancer, not } \\
\text { NMSC }\end{array}$ & $\begin{array}{l}3540 \\
(100 \%)\end{array}$ & $\begin{array}{l}19357 \\
(100 \%) \\
\end{array}$ & $236(6.7 \%)$ & $1664(8.6 \%)$ & 41551 & 263638 & $5.7(5.0-6.4)$ & $6.3(6.0-6.6)$ & $1.06(0.92-1.23)$ & $1.07\left(0.92-1.2 \frac{3}{\sqrt[3]{3}}\right)$ \\
\hline & & & & & & & & & & $\stackrel{\text { की }}{\stackrel{3}{(1)}}$ \\
\hline Oral cavity & $\begin{array}{l}3662 \\
(100 \%)\end{array}$ & $\begin{array}{l}20023 \\
(100 \%) \\
\end{array}$ & $9(0.2 \%)$ & $35(0.2 \%)$ & 43595 & 279041 & $0.2(0.1-0.3)$ & $0.1(0.1-0.2)$ & $1.93(0.88-4.22)$ & 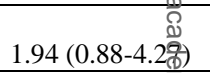 \\
\hline Solid & $\begin{array}{l}3542 \\
(100 \%)\end{array}$ & $\begin{array}{l}19361 \\
(100 \%)\end{array}$ & $254(7.2 \%)$ & $1672(8.6 \%)$ & 41485 & 263395 & $6.1(5.4-6.9)$ & $6.3(6.0-6.7)$ & $1.14(0.99-1.31)$ & $1.15\left(0.99-1.3 \frac{\bar{Q}}{2}\right)$ \\
\hline Hematological & $\begin{array}{l}3654 \\
(100 \%) \\
\end{array}$ & $\begin{array}{l}19999 \\
(100 \%) \\
\end{array}$ & $16(0.4 \%)$ & $148(0.7 \%)$ & 43518 & 278365 & $0.4(0.2-0.5)$ & $0.5(0.4-0.6)$ & $0.92(0.54-1.58)$ & $0.93(0.54-1.68)$ \\
\hline Lymphoproliferative & $\begin{array}{l}3658 \\
(100 \%)\end{array}$ & $\begin{array}{l}20004 \\
(100 \%) \\
\end{array}$ & $10(0.3 \%)$ & $122(0.6 \%)$ & 43564 & 278505 & $0.2(0.1-0.4)$ & $0.4(0.4-0.5)$ & $0.72(0.37-1.41)$ & $0.74(0.37-1.4 \stackrel{3}{3})$ \\
\hline GI-tract & $\begin{array}{l}3647 \\
(100 \%)\end{array}$ & $\begin{array}{l}19955 \\
(100 \%)\end{array}$ & $47(1.3 \%)$ & $361(1.8 \%)$ & 43468 & 277564 & $1.1(0.8-1.4)$ & $1.3(1.2-1.4)$ & $1.04(0.75$ & $1.05(0.76-1.4$ క్ํำ \\
\hline Gastric & $\begin{array}{l}3664 \\
(100 \%)\end{array}$ & $\begin{array}{l}20025 \\
(100 \%) \\
\end{array}$ & $5(0.1 \%)$ & $43(0.2 \%)$ & 43666 & 279160 & $0.1(0.0-0.2)$ & $0.2(0.1-0.2)$ & $0.94(0.36-2.48)$ & $0.90(0.33-2.4 \%)$ \\
\hline Colorectal & $\begin{array}{l}3648 \\
(100 \%)\end{array}$ & $\begin{array}{l}19972 \\
(100 \%)\end{array}$ & $30(0.8 \%)$ & $217(1.1 \%)$ & 43498 & 277876 & $0.7(0.4-0.9)$ & $0.8(0.7-0.9)$ & $1.08(0.72-1.61)$ & $1.10\left(0.73-1.6 \frac{\overline{\frac{0}{2}}}{\bar{\Phi}}\right)$ \\
\hline Liver & $\begin{array}{l}3664 \\
(100 \%) \\
\end{array}$ & $\begin{array}{l}20032 \\
(100 \%) \\
\end{array}$ & $6(0.2 \%)$ & $29(0.1 \%)$ & 43674 & 279229 & $0.1(0.0-0.2)$ & $0.1(0.1-0.1)$ & $1.61(0$. & $2.14\left(0.80-5.7 \frac{2}{8}\right)$ \\
\hline Pancreas & $\begin{array}{l}3664 \\
(100 \%)\end{array}$ & $\begin{array}{l}20031 \\
(100 \%) \\
\end{array}$ & $2(0.1 \%)$ & $52(0.3 \%)$ & 43669 & 279224 & $0.0(0.0-0.1)$ & $0.2(0.1-0.2)$ & $0.36(0.09-1.54)$ & $0.31\left(0.07-1.3 \frac{3}{4}\right)$ \\
\hline Lung & $\begin{array}{l}3661 \\
(100 \%) \\
\end{array}$ & $\begin{array}{l}20023 \\
(100 \%) \\
\end{array}$ & $5(0.1 \%)$ & $116(0.6 \%)$ & 43650 & 279047 & $0.1(0.0-0.2)$ & $0.4(0.3$ & $0.35(0.14-0.86)$ & $0.36\left(0.14-0.9 \frac{\vec{\alpha}}{\omega}\right)$ \\
\hline Breast & $\begin{array}{l}1095 \\
(29.9 \%)\end{array}$ & $\begin{array}{l}5779 \\
(29.0 \%) \\
\end{array}$ & $17(1.6 \%)$ & $152(2.6 \%)$ & 13925 & 80032 & $1.2(0.6-1.8)$ & $1.9(1.6-2.2)$ & $0.69(0.41-1.16)$ & $0.69(0.41-1.1 \stackrel{\underline{\overline{\mathrm{T}}}}{\mathrm{G}})$ \\
\hline Upper airways & $\begin{array}{l}3661 \\
(100 \%)\end{array}$ & $\begin{array}{l}20027 \\
(100 \%) \\
\end{array}$ & $2(0.1 \%)$ & $13(0.1 \%)$ & 43622 & 279196 & $0.0(0.0-0.1)$ & $0.0(0.0-0.1)$ & $1.57(0.32-7.80)$ & $5.03(0.68-37.08)$ \\
\hline Prostate & $\begin{array}{l}2544 \\
(69.8 \%)\end{array}$ & $\begin{array}{l}14078 \\
(70.6 \%) \\
\end{array}$ & $71(2.8 \%)$ & $442(3.1 \%)$ & 29151 & 194366 & $2.4(1.9-3.0)$ & $2.3(2.1-2.5)$ & $1.48(1.13-1.94)$ & $1.51(1.15-1.98)$ \\
\hline Renal/Urinary & $\begin{array}{l}3658 \\
(100 \%) \\
\end{array}$ & $\begin{array}{l}19989 \\
(100 \%) \\
\end{array}$ & $27(0.7 \%)$ & $144(0.7 \%)$ & 43553 & 278168 & $0.6(0.4-0.9)$ & $0.5(0.4-0.6)$ & $1.58(1.00-2.47)$ & $1.59(1.01-2.52)$ \\
\hline Nervous system & $\begin{array}{l}3659 \\
(100 \%)\end{array}$ & $\begin{array}{l}20003 \\
(100 \%) \\
\end{array}$ & $10(0.3 \%)$ & $49(0.2 \%)$ & 43561 & 278 & $0.2(0.1-0.4)$ & $0.2(0.1-0.2)$ & $1.27(0.63-2.57)$ & $1.25\left(0.61-2.5 \frac{\subsetneq}{\overline{6}}\right)$ \\
\hline Endocrine glands & $\begin{array}{l}3656 \\
(100 \%)\end{array}$ & $\begin{array}{l}20009 \\
(100 \%) \\
\end{array}$ & $5(0.1 \%)$ & $43(0.2 \%)$ & 43597 & & $0.1(0.0-0.2)$ & $0.2(0.1-0.2)$ & $0.75(0.29-1.95)$ & $0.76\left(0.29-1.9^{\frac{\mathbb{D}}{6}}\right)$ \\
\hline Penis/Testis & $\begin{array}{l}2558 \\
(69.9 \%) \\
\end{array}$ & $\begin{array}{l}14151 \\
(70.7 \%) \\
\end{array}$ & $2(0.1 \%)$ & $16(0.1 \%)$ & 295 & 196900 & $0.1(0.0-0.2)$ & $0.1(0.0-0.1)$ & $0.88(0.19-3.96)$ & $0.87(0.19-4.0$ 열 \\
\hline Vuvla/Vagina & $\begin{array}{l}1102 \\
(30.1 \%)\end{array}$ & \begin{tabular}{|l|}
5856 \\
$(29.2 \%)$
\end{tabular} & $(0.0 \%)$ & $6(0.1 \%)$ & 14061 & 81889 & $0.0(0.0-0.0)$ & $0.1(0.0-0.1)$ & N/A & N/A \\
\hline Cervis/Uterus/Ovaries & $\begin{array}{l}1067 \\
(29.4 \%)\end{array}$ & $\begin{array}{l}5651 \\
(28.5 \%)\end{array}$ & $16(1.5 \%)$ & $137(2.4 \%)$ & 13600 & 77941 & $1.2(0.6-1.8)$ & $1.8(1.5-2.1)$ & $0.65(0.39-1.11)$ & $0.64\left(0.38-1.0 \frac{\mathrm{O}}{\mathrm{O}}\right)$ \\
\hline Melanoma & $\begin{array}{l}3656 \\
(100 \%) \\
\end{array}$ & $\begin{array}{l}19988 \\
(100 \%) \\
\end{array}$ & $23(0.6 \%)$ & $140(0.7 \%)$ & 43472 & 277873 & $0.5(0.3-0.7)$ & $0.5(0.4-0.6)$ & $1.15(0.72-1.82)$ & $1.14\left(0.71-1.8 \overline{\frac{\mathrm{g}}{\mathrm{g}}}\right)$ \\
\hline Skeleton & $\begin{array}{l}3663 \\
(100 \%)\end{array}$ & $\begin{array}{l}20027 \\
(100 \%) \\
\end{array}$ & $1(0.0 \%)$ & & 43663 & 279194 & $0.0(0.0-0.1)$ & $0.0(0.0-0.0)$ & $5.00(0.31-79.95)$ & $3.00(0.19-47.96)$ \\
\hline NMSC & $\begin{array}{l}3657 \\
(100 \%)\end{array}$ & $\begin{array}{l}19998 \\
(100 \%)\end{array}$ & $39(1.1 \%)$ & & 43438 & 277961 & $0.9(0.6-1.2)$ & $0.7(0.6-0.7)$ & $1.88(1.29-2.76)$ & $1.90(1.29-2.7 \underline{\bar{Q}})$ \\
\hline
\end{tabular}

Table 3. Cancer risk in non-ESRD IgAN patients

IgAN: IgA nephropathy

ESRD: End stage renal disease

CI: Confidence interval

HR: Hazard Ratio

IR: Incidence rate per 1,000 person years

N/A: notable to calculate

NMSC: non-melanoma skin cancer

*Analyses run in strata of cases and 5 (sex, age, calendar-year, and county) matched controls additionally adjusted for smoking and educational attainment 


\begin{tabular}{|c|c|c|c|c|c|c|c|c|c|c|}
\hline Subgroups cancer & IgAN & Controls & $\begin{array}{l}\text { Cancer } \\
\text { events } \\
\text { IgAN }\end{array}$ & $\begin{array}{c}\text { Cancer } \\
\text { events } \\
\text { Controls }\end{array}$ & \begin{tabular}{|c|} 
Follow up \\
years \\
IgAN
\end{tabular} & \begin{tabular}{|c|} 
Follow up \\
years \\
Controls
\end{tabular} & $\begin{array}{l}\text { IR IgAN } \\
(95 \% \text { CI })\end{array}$ & $\begin{array}{c}\text { IR Controls } \\
(95 \% \text { CI })\end{array}$ & $\begin{array}{c}\mathrm{HR} \\
(\mathbf{9 5} \% \mathrm{CI})\end{array}$ & $\begin{array}{c}\mathrm{aHR}^{*} \\
(\mathbf{9 5 \%} \mathrm{CI})\end{array}$ \\
\hline Any_cancer & \begin{tabular}{|l|l|}
984 \\
$(100 \%)$
\end{tabular} & \begin{tabular}{|l|}
4861 \\
$(100 \%)$
\end{tabular} & $224(22.8 \%)$ & $483(9.9 \%)$ & 8556 & 53143 & $26.2(22.8-29.6)$ & $9.1(8.3-9.9)$ & $3.97(3.30-4.77)$ & $4.01(3.33-4.8$ \\
\hline $\begin{array}{l}\text { Any cancer, } \\
\text { not_NMSC }\end{array}$ & \begin{tabular}{|l|l|}
$\begin{array}{l}1004 \\
(100 \%)\end{array}$ \\
\end{tabular} & \begin{tabular}{|l|}
4874 \\
$(100 \%)$
\end{tabular} & $131(13.0 \%)$ & $446(9.2 \%)$ & 9336 & 53447 & $14.0(11.6-16.4)$ & $8.3(7.6-9.1)$ & $2.20(1.78-2.73)$ & $2.22(1.79-2.7$ \\
\hline Oral cavity & \begin{tabular}{|l|}
1066 \\
$(100 \%)$
\end{tabular} & $\begin{array}{l}5105 \\
(100 \%)\end{array}$ & $10(0.9 \%)$ & $9(0.2 \%)$ & 10247 & 57342 & $1.0(0.4-1.6)$ & $0.2(0.1-0.3)$ & $5.55(2.18-14.11)$ & $5.36(2.07-13.8$ \\
\hline Solid & $\begin{array}{l}984 \\
(100 \%)\end{array}$ & $\begin{array}{l}\begin{array}{l}4871 \\
(100 \%)\end{array} \\
\end{array}$ & $219(22.3 \%)$ & $452(9.3 \%)$ & 8583 & 53367 & $25.5(22.1-28.9)$ & $8.5(7.7-9.3)$ & $4.21(3.48-5.09)$ & $4.25(3.51-5.1$ \\
\hline Hematological & $\begin{array}{l}1064 \\
(100 \%)\end{array}$ & $\begin{array}{l}5100 \\
(100 \%)\end{array}$ & $15(1.4 \%)$ & $44(0.9 \%)$ & 10286 & 57149 & $1.5(0.7-2.2)$ & $0.8(0.5-1.0)$ & $2.34(1.25-4.38)$ & 2.39 (1.26-4.5 \\
\hline Lymphoproliferative & \begin{tabular}{|l|l|}
1064 \\
$(100 \%)$
\end{tabular} & \begin{tabular}{|l|l|}
5102 \\
$(100 \%)$
\end{tabular} & $13(1.2 \%)$ & $35(0.7 \%)$ & 10286 & 57197 & $1.3(0.6-2.0)$ & $0.6(0.4-0.8)$ & $2.63(1.33-5.20)$ & $2.82(1.40-5.6)$ \\
\hline GI-tract & $\begin{array}{l}1055 \\
(100 \%)\end{array}$ & $\begin{array}{l}5079 \\
(100 \%) \\
\end{array}$ & $29(2.7 \%)$ & $105(2.1 \%)$ & 10189 & 56916 & $2.8(1.8-3.9)$ & $1.8(1.5-2.2)$ & $1.81(1.17-2.79)$ & $1.76\left(1.13-2.73^{3}\right.$ \\
\hline Gastric & \begin{tabular}{|l|l|}
1067 \\
$(100 \%)$
\end{tabular} & \begin{tabular}{|l|l|}
5108 \\
$(100 \%)$
\end{tabular} & $1(0.1 \%)$ & $14(0.3 \%)$ & 10335 & 57390 & $0.1(0.0-0.3)$ & $0.2(0.1-0.4)$ & $0.35(0,05-2.69)$ & $0.32(0.04-2.56)$ \\
\hline Colorectal & $\begin{array}{l}1056 \\
(100 \%)\end{array}$ & $\begin{array}{l}5084 \\
(100 \%) \\
\end{array}$ & $22(2.1 \%)$ & $58(1.1 \%)$ & 10197 & 56995 & $2.2(1.3-3.1)$ & $1.0(0.8-1.3)$ & $2.61(1.53-4.45)$ & $2.66(1.53-4.62$ \\
\hline Liver & $\begin{array}{l}1066 \\
(100 \%)\end{array}$ & $\begin{array}{l}5110 \\
(100 \%) \\
\end{array}$ & $1(0.1 \%)$ & $8(0.2 \%)$ & 10335 & 57387 & $0.1(0.0-0.3)$ & $0.1(0.0-0.2)$ & $0.92(0.14-7.93)$ & $1.30(0.13-13$. \\
\hline Pancreas & $\begin{array}{l}1067 \\
(100 \%) \\
\end{array}$ & $\begin{array}{l}5110 \\
(100 \%) \\
\end{array}$ & $3(0.3 \%)$ & $18(0.4 \%)$ & 10335 & 57390 & $0.3(0.0-0.6)$ & $0.3(0.2-0.5)$ & $1.11(0.31-3.96)$ & \\
\hline Lung & $\begin{array}{l}1067 \\
(100 \%)\end{array}$ & $\begin{array}{l}5105 \\
(100 \%)\end{array}$ & $3(0.3 \%)$ & $33(0.6 \%)$ & 10334 & 57363 & $0.3(0.0-0.6)$ & $0.6(0.4-0.8)$ & $0.76(0.22-2.59)$ & $0.88(0.24-3.2$ \\
\hline Breast & \begin{tabular}{|l|}
199 \\
$(18.7 \%)$
\end{tabular} & \begin{tabular}{|l|}
980 \\
$(19.2 \%)$ \\
\end{tabular} & $4(2.0 \%)$ & $31(3.2 \%)$ & 2108 & 11312 & $1.9(0.0-3.8)$ & $2.7(1.8-3.7)$ & $0.77(0.26-2.23)$ & $0.74(0.25-2.17$ \\
\hline Upper airways & \begin{tabular}{|l|l|}
1067 \\
$(100 \%)$
\end{tabular} & \begin{tabular}{|l|l|}
5108 \\
$(100 \%)$
\end{tabular} & $1(0.1 \%)$ & $6(0.1 \%)$ & 10330 & 57377 & $0.1(0.0-0.3)$ & $0.1(0.0-0.2)$ & $1.07(0.12-9.62)$ & $1.42(0.14-14.7$ \\
\hline Prostate & \begin{tabular}{|l|}
854 \\
$(80.9 \%)$
\end{tabular} & $\begin{array}{l}4071 \\
(80.4 \%)\end{array}$ & $25(2.9 \%)$ & $154(3.8 \%)$ & 8027 & 44867 & $3.1(1.9-4.3)$ & $3.4(2.9-4.0)$ & $1.26(0.80-1.97)$ & $1.32(0.84-2.07 \overline{9}$ \\
\hline Renal/Urinary & \begin{tabular}{|l|l|}
1055 \\
$(100 \%)$
\end{tabular} & \begin{tabular}{|l|l|}
5091 \\
$(100 \%)$
\end{tabular} & $25(2.4 \%)$ & $45(0.9 \%)$ & 10200 & 57085 & $2.5(1.5-3.4)$ & $0.8(0.6-1.0)$ & $3.81(2.22-6.56)$ & $4.12(2.35-7.225$ \\
\hline Nervous system & \begin{tabular}{|l|}
1065 \\
$(100 \%)$
\end{tabular} & $\begin{array}{l}\begin{array}{l}5102 \\
(100 \%)\end{array} \\
\end{array}$ & $3(0.3 \%)$ & $9(0.2 \%)$ & 10308 & & $0.3(0.0-0.6)$ & $0.2(0.1-0.3)$ & $1.96(0.50-7.57)$ & $2.28(0.52-10.0$ \\
\hline Endocrine glands & $\begin{array}{l}1063 \\
(100 \%)\end{array}$ & \begin{tabular}{|l|}
5098 \\
$(100 \%)$
\end{tabular} & $9(0.8 \%)$ & $12(0.2 \%)$ & 10251 & & $0.9(0.3-1.5)$ & $0.2(0.1-0.3)$ & $4.23(1.72-10.43)$ & $4.46(1.70-11.79$ \\
\hline Penis/Testis & \begin{tabular}{|l|}
863 \\
$(81.1 \%)$
\end{tabular} & $\begin{array}{l}4107 \\
(80.5 \%)\end{array}$ & $(0.0 \%)$ & $2(0.0 \%)$ & 170 & 45669 & $0.0(0.0-0.0)$ & $0.0(0.0-0.1)$ & N/A & N/A \\
\hline Vulva/Vagina & $\begin{array}{l}201 \\
(18.8 \%)\end{array}$ & $\begin{array}{l}995 \\
(19.5 \%)\end{array}$ & $5(2.5 \%)$ & $(0.0 \%)$ & (2) & 11631 & $2.4(0.3-4.5)$ & $0.0(0.0-0.0)$ & N/A & N/A \\
\hline Cervix/Uterus/Ovaries & \begin{tabular}{|l|}
188 \\
$(17.8 \%)$ \\
\end{tabular} & \begin{tabular}{|l|}
936 \\
$(18.5 \%)$ \\
\end{tabular} & $5(2.7 \%)$ & $20(2.1 \%)$ & 1970 & 10790 & $2.5(0.3-4.8)$ & $1.9(1.0-2.7)$ & $1.33(0.48-3.69)$ & $1.26(0.41-3.8$ \\
\hline Melanoma & $\begin{array}{l}1063 \\
(100 \%)\end{array}$ & \begin{tabular}{|l|}
5093 \\
$(100 \%)$
\end{tabular} & $12(1.1 \%)$ & $30(0.6 \%)$ & 10253 & 57037 & $1.2(0.5-1.8)$ & $0.5(0.3-0.7)$ & $2.49(1.22-5.08)$ & $2.30(1.11-4.78)$ \\
\hline Skeleton & $\begin{array}{l}1067 \\
(100 \%)\end{array}$ & $\begin{array}{l}5110 \\
(100 \%)\end{array}$ & $(0.0 \%)$ & $(0.0 \%)$ & 10336 & 57408 & $0.0(0.0-0.0)$ & $0.0(0.0-0.0)$ & N/A & \\
\hline NMSC & $\begin{array}{l}1045 \\
(100 \%)\end{array}$ & $\begin{array}{l}5093 \\
(100 \%)\end{array}$ & $139(13.3 \%)$ & $53(1.0 \%)$ & 9348 & 57048 & 14.9 (12.4-17.3) & $0.9(0.7-1.2)$ & \begin{tabular}{|l|}
$27.45(17.49-$ \\
$43.09)$
\end{tabular} & $\begin{array}{l}28.51(17.90- \\
45.41)\end{array}$ \\
\hline $\begin{array}{l}\text { IgA } \\
\text { ESF } \\
\text { CI: } \\
\text { HR } \\
\text { IR: } \\
\text { N/A } \\
\text { NM }\end{array}$ & $\begin{array}{l}\text { N: IgA } \\
\text { D: En } \\
\text { Confid } \\
\text { Hazar } \\
\text { Inciden } \\
\text { : not al } \\
\text { SC: no } \\
\text { lalyses } \\
\text { itionall }\end{array}$ & $\begin{array}{l}\text { nephro } \\
\text { d stage } \\
\text { ence int } \\
\text { d Ratio } \\
\text { ice rate } \\
\text { ble to ce } \\
\text { n-melar } \\
\text { run in s } \\
\text { v adiust }\end{array}$ & $\begin{array}{l}\text { pathy } \\
\text { enal dise } \\
\text { erval } \\
\text { per } 1,000 \\
\text { lculate } \\
\text { loma skin } \\
\text { trata of ca } \\
\text { ed for sm }\end{array}$ & $\begin{array}{l}\text { person y } \\
\text { cancer } \\
\text { ses and } 5 \\
\text { king and }\end{array}$ & , & SRD & ear, an & ity) $m$ & ed contro & \\
\hline
\end{tabular}


Figure 1: Cancer risk in patients with IgAN

\begin{tabular}{|c|c|}
\hline [CELLRANGE] & [CELLRANGE] \\
\hline [CELLRANGE] & [CELLRANGE] \\
\hline [CELLRANGE] & [CELLRANGE] \\
\hline [CELLRANGE] & [CELLRANGE] \\
\hline [CELLRANGE] & [CELLRANGE] \\
\hline [CELLRANGE] & [CELLRANGE] \\
\hline [CELLRANGE] & [CELLRANGE] \\
\hline [CELLRANGE] & [CELLRANGE] \\
\hline [CELLRANGE] & [CELLRANGE] \\
\hline [CELLRANGE] & [CELLRANGE] \\
\hline [CELLRANGE] & [CELLRANGE] \\
\hline [CELLRANGE] & [CELLRANGE] \\
\hline [CELLRANGE] & [CELLRANGE] \\
\hline [CELLRANGE] & [CELLRANGE] \\
\hline [CELLRANGE] & [CELLRANGE] \\
\hline [CELLRANGE] & [CELLRANGE] \\
\hline [CELLRANGE] & [CELLRANGE] \\
\hline [CELLRANGE] & [CELLRANGE] \\
\hline [CELLRANGE] & [CELLRANGE] \\
\hline [CELLRANGE] & [CELLRANGE] \\
\hline [CELLRANGE] & [CELLRANGE] \\
\hline [CELLRANGE] & [CELLRANGE] \\
\hline [CELLRANGE] & [CELLRANGE] \\
\hline [CELLRANGE] & [CELLRANGE] \\
\hline
\end{tabular}

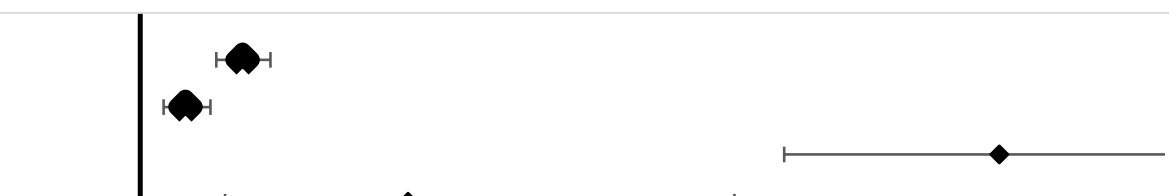

IgAN: IgA nephropathy

HR: Hazard Ratio

CI: Confidence interval

NMSC: non-melanoma skin cancer

GI-tract: gastrointestinal tract 
Figure 2: Cancer risk in non-ESRD IgAN patients

\begin{tabular}{|c|c|}
\hline [CELLRANGE] & [CELLRANGE] \\
\hline [CELLRANGE] & [CELLRANGE] \\
\hline [CELLRANGE] & [CELLRANGE] \\
\hline [CELLRANGE] & [CELLRANGE] \\
\hline [CELLRANGE] & [CELLRANGE] \\
\hline [CELLRANGE] & [CELLRANGE] \\
\hline [CELLRANGE] & [CELLRANGE] \\
\hline [CELLRANGE] & [CELLRANGE] \\
\hline [CELLRANGE] & [CELLRANGE] \\
\hline [CELLRANGE] & [CELLRANGE] \\
\hline [CELLRANGE] & [CELLRANGE] \\
\hline [CELLRANGE] & [CELLRANGE] \\
\hline [CELLRANGE] & [CELLRANGE] \\
\hline [CELLRANGE] & [CELLRANGE] \\
\hline [CELLRANGE] & [CELLRANGE] \\
\hline [CELLRANGE] & [CELLRANGE] \\
\hline [CELLRANGE] & [CELLRANGE] \\
\hline [CELLRANGE] & [CELLRANGE] \\
\hline [CELLRANGE] & [CELLRANGE] \\
\hline [CELLRANGE] & [CELLRANGE] \\
\hline [CELLRANGE] & [CELLRANGE] \\
\hline [CELLRANGE] & [CELLRANGE] \\
\hline [CELLRANGE] & [CELLRANGE] \\
\hline [CELLRANGE] & [CELLRANGE] \\
\hline
\end{tabular}

$-5$

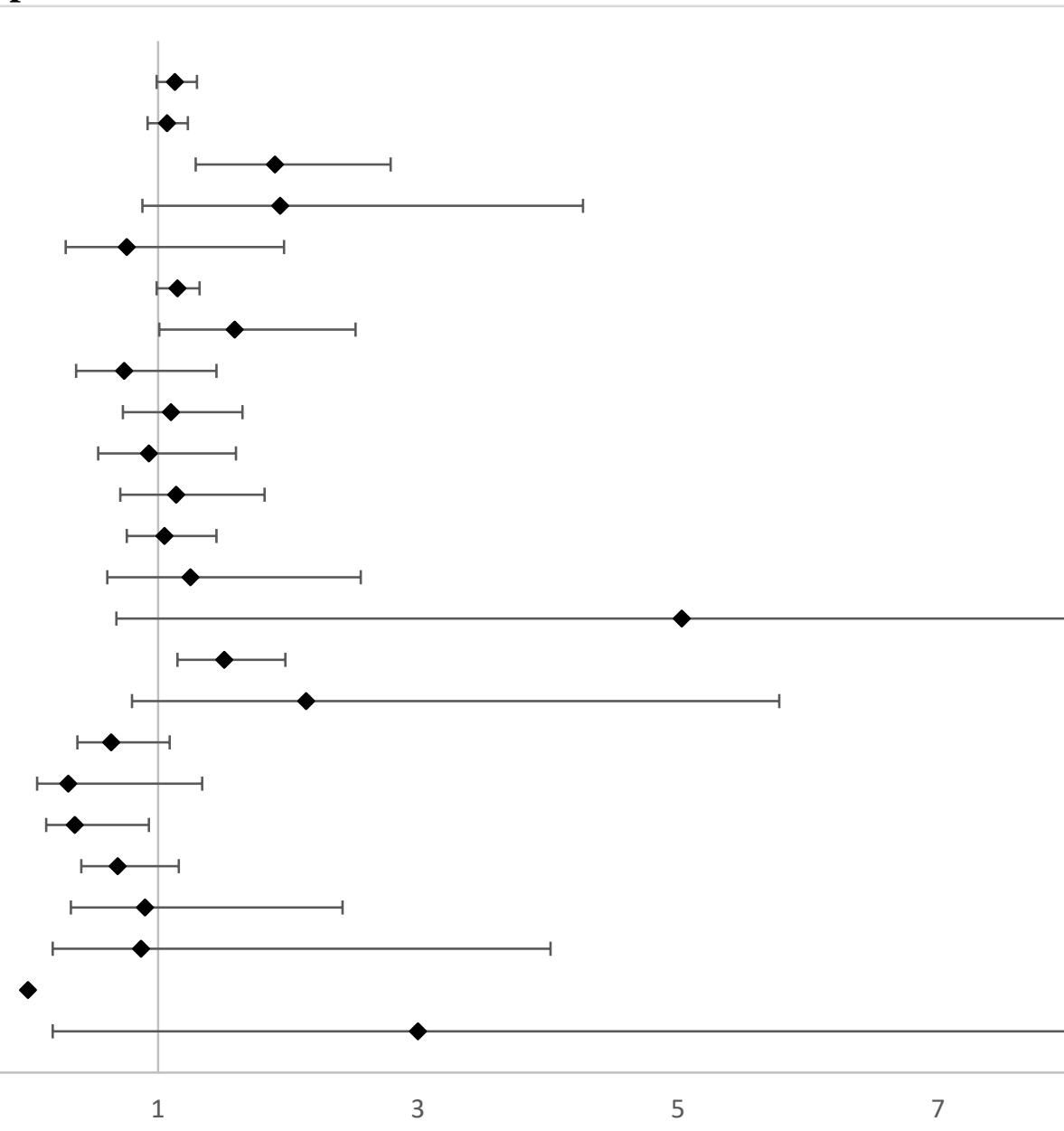

IgAN: IgA nephropathy

ESRD: End stage renal disease

HR: Hazard Ratio

CI: Confidence interval

NMSC: non-melanoma skin cancer

GI-tract: gastrointestinal tract

N/A: not able to calculate 
Figure 3: Cancer risk in IgAN patients with ESRD

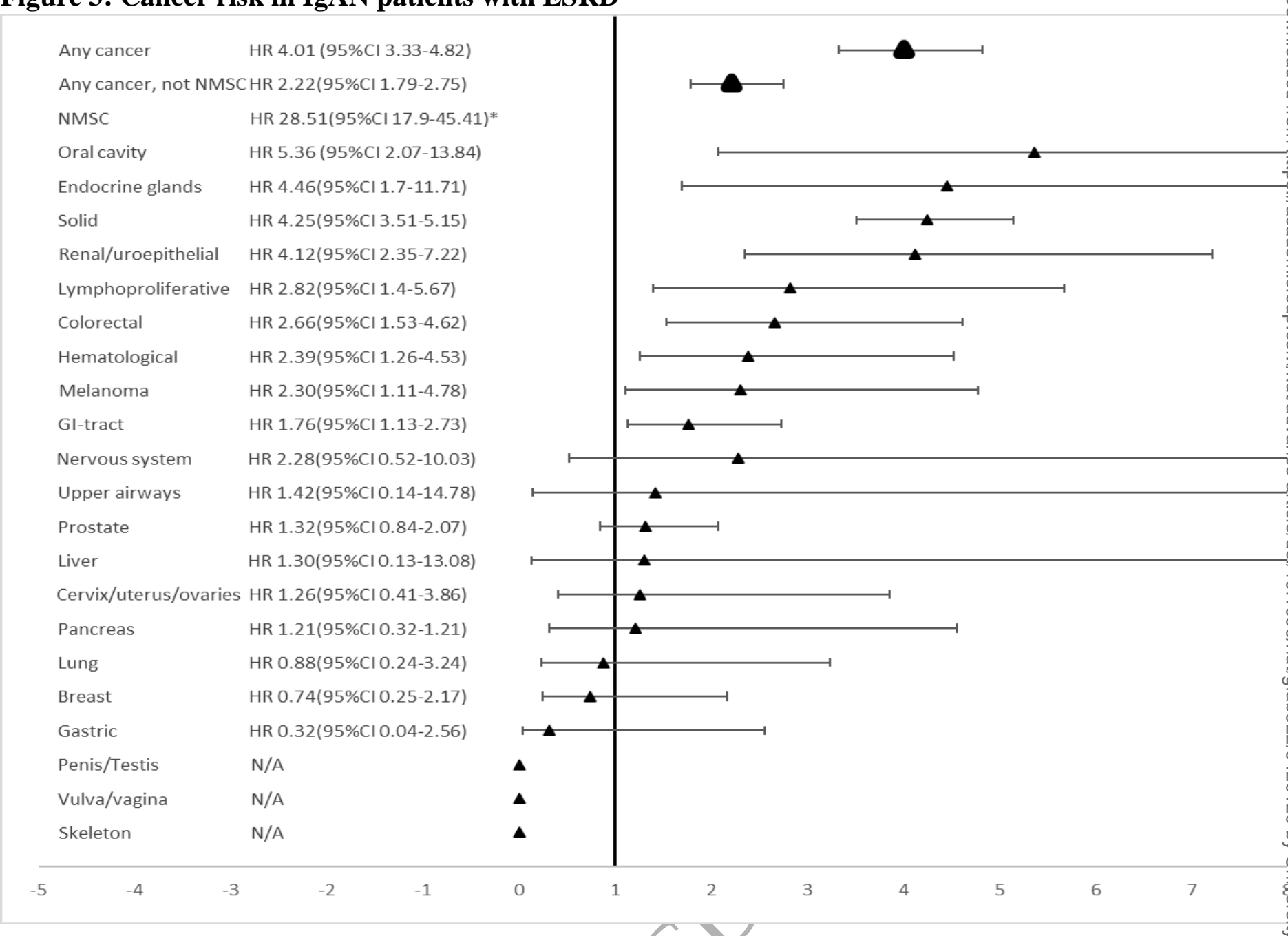

IgAN: IgA nephropathy

ESRD: End stage renal disease

HR: Hazard Ratio

CI: Confidence interval

NMSC: non-melanoma skin cancer

GI-tract: gastrointestinal tract

N/A: not able to calculate

*Not in graph 
Figure 4: Cancer risk in IgAN patients with kidney transplant

\begin{tabular}{|c|c|}
\hline [CELLRANGE] & [CELLRANGE] \\
\hline [CELLRANGE] & [CELLRANGE] \\
\hline [CELLRANGE] & [CELLRANGE] \\
\hline [CELLRANGE] & [CELLRANGE] \\
\hline [CELLRANGE] & [CELLRANGE] \\
\hline [CELLRANGE] & [CELLRANGE] \\
\hline [CELLRANGE] & [CELLRANGE] \\
\hline [CELLRANGE] & [CELLRANGE] \\
\hline [CELLRANGE] & [CELLRANGE] \\
\hline [CELLRANGE] & [CELLRANGE] \\
\hline [CELLRANGE] & [CELLRANGE] \\
\hline [CELLRANGE] & [CELLRANGE] \\
\hline [CELLRANGE] & [CELLRANGE] \\
\hline [CELLRANGE] & [CELLRANGE] \\
\hline [CELLRANGE] & [CELLRANGE] \\
\hline [CELLRANGE] & [CELLRANGE] \\
\hline [CELLRANGE] & [CELLRANGE] \\
\hline [CELLRANGE] & [CELLRANGE] \\
\hline [CELLRANGE] & [CELLRANGE] \\
\hline [CELLRANGE] & [CELLRANGE] \\
\hline [CELLRANGE] & [CELLRANGE] \\
\hline [CELLRANGE] & [CELLRANG \\
\hline [CELLRANGE] & [CELLRANC \\
\hline [CELLRANGE] & [CELLRAN \\
\hline
\end{tabular}

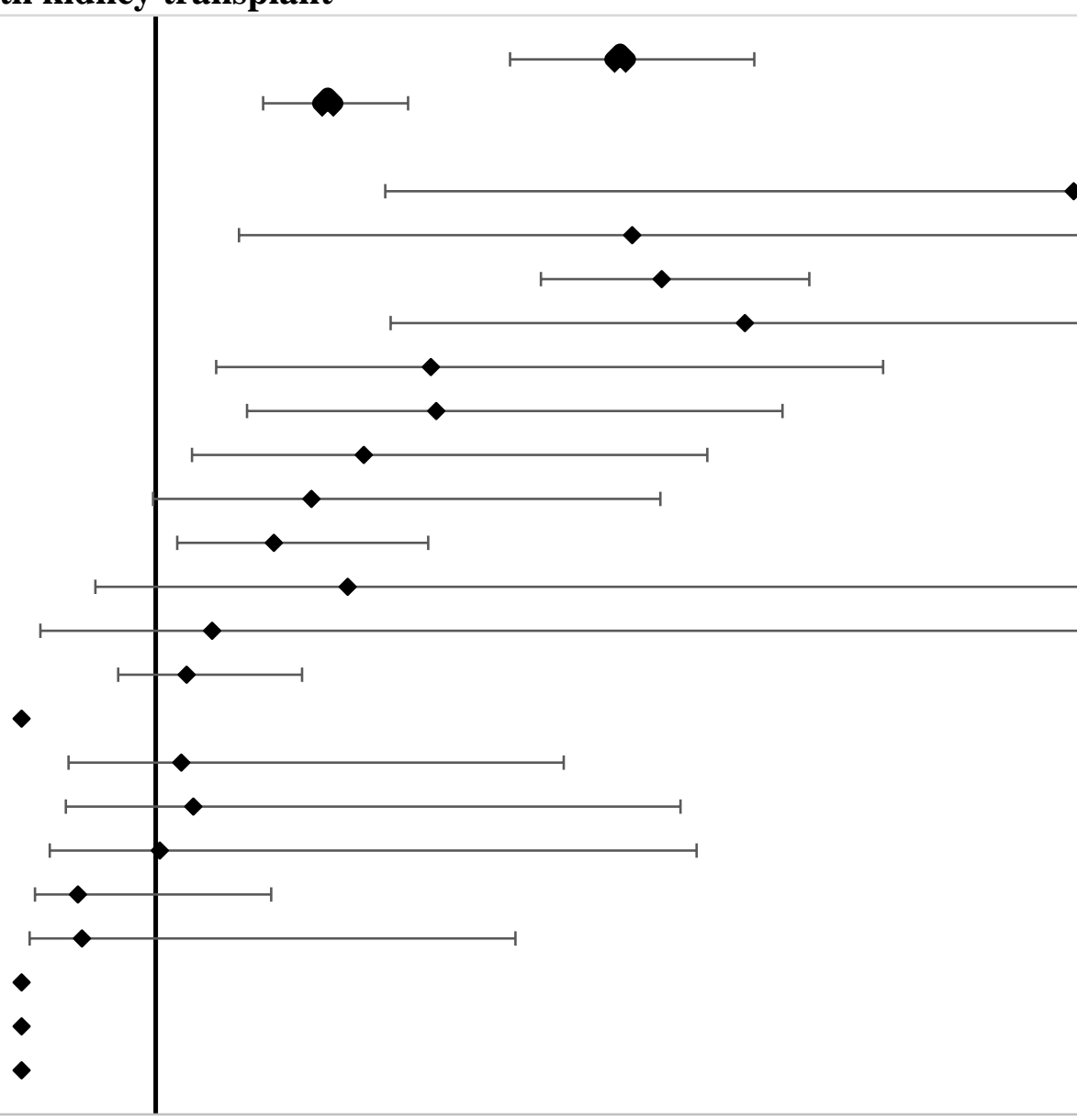

IgAN: IgA nephropathy

HR: Hazard Ratio

CI: Confidence interval

NMSC: non-melanoma skin cancer

GI-tract: gastrointestinal tract

N/A: not able to calculate

*Not in graph 